\title{
Modificação na técnica para montagem de simulídeos (Insecta, Diptera) em lâmina/lamínula
}

\author{
Regina H. dos S. Calvão-Brito \& Marilza Maia-Herzog
}

Departamento de Entomologia, Instituto Oswaldo Cruz. Avenida Brasil 4365, 21045-900 Rio de Janeiro, Rio de Janeiro, Brasil.E-mail: rcalvaob@gene.dbbm.fiocruz.br

\begin{abstract}
Modification in the mounting technique of simulim (Insecta, Diptera) on glass slides. A technique to mounting simulium is modified and presented.
\end{abstract}

KEY WORDS. Simulium, morphology, mounting technique.

No Brasil, o estudo morfo-taxonômico dos simulídeos teve início com os trabalhos de LuTz (1909), que versavam sobre as espécies brasileiras de simulídeos visando auxiliar e facilitar o conhecimento destes dípteros no País.

O estudo dos simulídeos tornou-se importante pelo fato destes serem vetores de agentes etiológicos de várias doenças, tanto para o homem como para os animais.

No mundo existem aproximadamente 1000 espécies descritas e no Brasil estão listadas 55 espécies (Crosskey 1987).

Para o desenvolvimento de estudos taxonômicos, ecológicos e ou epidemiológicos é necessário a preparação adequada de exemplares de Simulidae (Diptera), o que é realizado através de montagens entre lâmina e lamínula, montagem em alfinetes entomológicos (com utilização de microalfinetes) e conservados em álcool a 70\%. A montagem do material entre lâmina/lamínula (VоскеRотн 1966) é uma das formas de preservação de exemplares e auxilia outros entomologistas em identificações futuras, quando fazem parte de uma Coleção de Referência para identificação. Esta técnica vem sofrendo modificações (JoNEs 1967).

O líquido utilizado nesta preservação, vem sendo substituído ao longo dos anos, visando a obtenção de melhor qualidade do material a ser examinado. Atualmente, usa-se o meio de Berlese (MarTin 1977) que proporciona observação mais apurada dos caracteres necessários à identificação, uma vez que este líquido é menos viscoso que o Bálsamo do Canadá.

Na técnica habitual para montagem de lâminas, o tempo médio para o preparo de cada exemplar era de 60 minutos. Modificou-se esta técnica e testou-se inicialmente em 50 exemplares de simulídeos. Foi obtido, na montagem completa de um exemplar, incluindo a dissecção, o tempo de 30 minutos. Os resultados também foram mais satisfatórios quanto as condições do exemplar à observação detalhada, sob microscópio, e passou-se a utilizá-la como de rotina para nossas montagens.
A seguir, é descrito o procedimento para montagem de lâmina/lamínula com modificações propostas.

\section{Adultos}

1) Separar cabeça, tórax, abdome, asas e patas em placa de Petri contendo álcool a 70\%.

2) Passar cabeça, tórax e abdome para $\mathrm{KOH} 10 \%$ e levar ao forno de microondas (posição descongelar - 35\% de $700 \mathrm{~W}$ de potência) por um ou dois minutos.

3) Levar cabeça, tórax, abdome, patas e asas ao HAC (glacial) por 10 minutos.

4) Passar todas as peças para Berlese "Storage" (sem goma arábica).

5) Montar em líquido de Berlese.

Pupas

1) Dissecar os exemplares em placa de Petri com álcool a $70 \%$.

2) Separar o casulo da exúvia da pupa.

3) Passar a exúvia da pupa para $\mathrm{KOH} 10 \%$ e levar ao forno de microondas (posição descongelar - 35\% de $700 \mathrm{~W}$ de potência) por um ou dois minutos.

4) Passar a exúvia da pupa e o casulo para HAC (glacial) por 10 minutos.

5) Passar as peças para Berlese "Storage".

6) Montar em líquido de Berlese.

\section{Larvas}

1) Separar cabeça, corpo e histoblastos respiratórios em placa de Petri com álcool a 70\%.

2) Passar cabeça e corpo para $\mathrm{KOH} 10 \%$ e levar ao forno de microondas (posição descongelar - 35\% de $700 \mathrm{~W}$ de po- 
tência) por um ou dois minutos.

3) Passar cabeça, corpo e histoblastos respiratórios para HAC (glacial) por 10 minutos.

4) Passar todas as peças para Berlese "Storage".

5) Montar em líquido de Berlese.

\section{REFERÊNCIAS BIBLIOGRÁFICAS}

LuTz, A. 1909. Contribuição para o conhecimento das espécies brasileiras do gênero Simulium. Memórias do Instituto Oswaldo Cruz, Rio de Janeiro, 1: 124-146.

Crosskey, R.W. 1987. An annotated checklist of the world black

Recebido em 21.II.2003; aceito em 10.XI.2003. flies (Diptera: Simuliidae). Part. VIII. Black fly species of the world, p. 425-520. In: K.C. Kim, R.W. Merritt (Eds). Black flies: ecology, population management, and annotated world list. The Pennsylvania State University.

VocкеRoth, J.R. 1966. A method of mounting insects from alcohol. Canadian Entmologist 98: 69-70.

JoNEs, J.C. 1967 Methods for dissecting. Mosquitoes News, Michigan, 3: 70-81.

Martin, J.E.H. 1977. The insects and arachnids of Canada. Part I. Collecting, preparing and preserving insects, mites, and spiders. Ottawa, Canadian Department of Agriculture Research Branch, Publication no. 1943, 182p.

Revista Brasileira de Zoologia 20 (4): 773-774, dezembro 2003 